\title{
Trans isomer content of infant milk formulas
}

\author{
JJ Permanyer 1, BA Pinto 2, N Hernández 2, J Boatella 2 \\ 1 ORDESA SA, Analytical Research Laboratory, c/Lepanto 410-414, 08025 Barcelona; \\ 2 Pharmacy School, Department of Physiological Sciences and Nutrition, \\ University of Barcelona, Barcelona, Spain
}

(Received 5 August 1989; accepted 20 March 1990)

\begin{abstract}
Summary - Infrared (IR) spectroscopy and capillary gas chromatography (CGC) were used to investigate the trans isomer content of infant milk formulas. For this purpose we analysed 28 samples from the Spanish market for the total trans isomer content (IR-spectroscopy) and for octadecenoic (C18:1 and C18:2) isomers (CGC). Our results show that infant milk formulas have low levels of trans isomers and they comply with the EEC Proposal 85/C28/05.
\end{abstract}

trans isomer / infant milk formula / IR spectroscopy / capillary gas chromatography

Résumé - Isomères trans dans des laits infantiles. Le dosage des isomères trans dans des préparations pour allaitement des nourrissons a été mis en œuvre par spectroscopie dans l'infrarouge (IR) et par chromatographie capillaire en phase gazeuse. Pour cette étude, nous avons analysé 28 échantillons du marché espagnol pour quantifier les isomères trans de manière globale (spectroscopie IR) et pour isoler les différentes formes isomériques de l'acide octadécenoïque, particulier du C18:1 et C18:2. Nos résultats montrent que les laits pour nourrissons analysés ont une faible teneur en isomères trans et sont en accord avec la proposition de la CEE 85/C28/05.

isomère trans / lait pour nourrisson / spectroscopie IR / chromatographie capillaire phase gazeuse

\section{INTRODUCTION}

Fatty acid composition of dairy products has received widespread attention (Parodi, 1983; Hachey et al, 1987; Koletzko et al, 1988). One of the reasons is the complex range of substances that arise as a result of isomerization in fatty acid unsaturation sites, which accompany hydrogenation by the rumen microbes of the unsaturated feed lipids to yield a mixture of geometrical and positional isomers, which are transmitted to the milk. Amount and type of feed can influence the microbiological population of the rumen and this can influence hydrogenation and formation of trans isomers in milk fat. In addition, seasonal feed variation results in higher unsaturated fatty acid levels in summer than in winter. Total isolated trans fatty acids in milkfat reported in the literature range from 2 to $11 \%$ with maximal values in the pasture feeding period due to hydrogenation and uptake of fat rich in $\mathrm{C}_{18: 2}$ and $\mathrm{C}_{18: 3}$ from fresh grass and minimal values in indoor feeding period (Deman and Deman, 1983; Sommerfeld, 1983; Zegarska and Kuzdzal-Savoie, 1988). 
In the case of infant milk formulas, milkfat is totally or partially substituted by a vegetable fat in order to achieve a similar fatty acid composition to the mother's milk. This vegetable fat can be obtained by hydrogenation of unsaturated vegetable oils and in this process, trans isomers of fatty acids can be produced. Therefore, the total trans isomer content of infant milk formulas is a consequence of the milkfat composition and the trans fatty acid content of hydrogenated vegetable fat used as raw material in their production.

On the other hand, there is an interest among nutritional research workers and governments as to whether there is any risk to health associated with the consumption of trans fatty acids (Emken, 1981; Kummerow, 1986) and in this sense, the EEC proposal 85/C28/05 limits the trans fatty acid content at $8 \%$ in raw materials used in infant milk formulas.

The objective of our study was to investigate and quantify the trans isomers in several samples of formulas used in infant feeding in order to establish the general situation of these kinds of foods.

\section{MATERIAL AND METHODS}

We have analysed 28 samples of infant milk formulas from the Spanish market, including :

- adapted formulas (AD): For infants between 0 and 4-6 months (10 samples);

- follow-up formulas (FU): For infants between 4-6 and 12 months (7 samples);

- pre-term infant formulas (PT): For low birth weight infants (3 samples);

- special formulas (SP): For lactose and cow's milk protein intolerances (8 samples).

Ingredient composition was noted from labels in order to correlate results with raw materials used by manufacturers (whole milk, skimmed milk, vegetable fat, etc).

\section{Extraction}

The extraction procedure is based on the RöseGottlieb method (FIL 123-1985) (Lee, 1987). Weight ca $10 \mathrm{~g}$ to the nearest milligram into fatextraction flask. Add $2 \mathrm{ml}$ ammonium hydroxide and mix thoroughly. Add $10 \mathrm{ml}$ ethyl alcohol and shake well. Add $25 \mathrm{ml}$ ethyl ether to sample and shake vigorously for $1 \mathrm{~min}$. Finally, add $25 \mathrm{ml}$ petroleum ether and shake vigorously for $1 \mathrm{~min}$. Centrifuge flask and decant ether layer. Conduct a second extraction using $5 \mathrm{ml}$ ethanol and 25 $\mathrm{ml}$ of each ether. Combine ether extracts in round-bottom flask and rotary evaporate solvents at $\mathrm{ca} 80^{\circ} \mathrm{C}$.

\section{Infrared spectroscopy}

One gram of the fatty extract was dissolved in $10 \mathrm{ml}$ of carbon disulfide and placed in a sodium chloride cell of $0.2 \mathrm{~mm}$ thickness in a Perkin Elmer FT-1710 infrared spectrophotometer. The measurement was taken at $966 \mathrm{~cm}^{-1}$.

Results are expressed as a percentage of elaidate in the fatty extract by using a calibration curve with methyl elaidate as a standard.

\section{Capillary gas chromatography}

Methylation of the fatty extract is performed according to Slover and Lanza (1979) with the mixture $\mathrm{BF}_{3} / \mathrm{CH}_{3} \mathrm{OH}$ as a reagent.

The identification of each peak was carried out by using standard fatty acid methyl esters (Merck, Sigma and Supelco) and retention time data from bibliography (Hernandez, 1988).

\section{Chromatographic conditions}

System : Perkin Elmer Chromatograph. Sigma 300, FID. Integrator HP 3390 A; Column: Fused Silica WCOT, CP-Sil $88,50 \mathrm{~m} \times 0.25 \mathrm{~mm} \mathrm{ID}$; Oven temperature: $190^{\circ} \mathrm{C}$ (isoterm); Injector temperature: $270{ }^{\circ} \mathrm{C}$; Detector temperature: $300^{\circ} \mathrm{C}$; Sample volume: $0.15 \mu \mathrm{l}$; Split: $1 / 100$; Carrier gas: He; Pressure carrier gas: 2 bar. 


\section{RESULTS AND DISCUSSION}

A typical fatty acid chromatogram of infant milk formulas is shown in figure 1. Using our chromatograph conditions, satisfactory separation was obtained of $\mathrm{C}_{16: 1}$ (cis and trans), $\mathrm{C}_{18: 1}$ (cis and trans), $\mathrm{C}_{18: 2}$ (cc, ct, $t c$, tt) and $\mathrm{C}_{18: 3}$ (ccc) from other transisomers of $\mathrm{C}_{18: 3}$.

Table I shows the amount of total trans isomers in the different infant formulas analysed using IR spectroscopy and capillary gas chromatography (CGC). These results range between 0.16 and $4.55 \%$, and the analysis of variance (ANOVA) shows a statistically significant correlation $(P<0.1)$ in the trans isomer content determinated either by the IR or CGC technique, in spite of the triglyceride interference in the IR technique (Deman and Deman, 1983).

On the other hand, the ANOVA test shows no significant difference between the trans isomer content of the 4 groups of

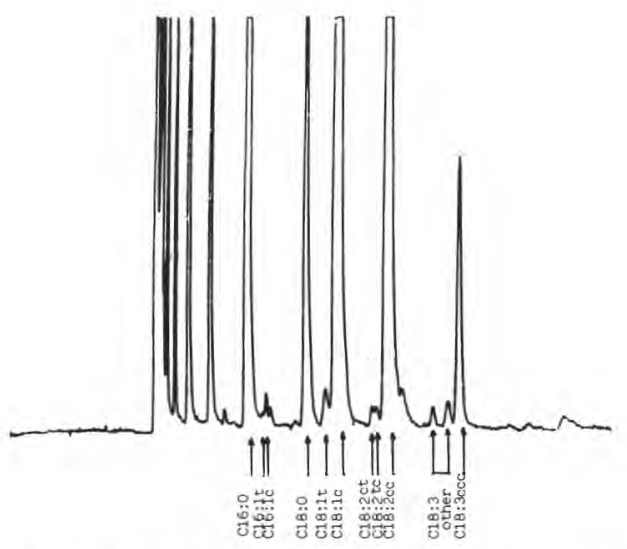

Fig 1. Typical chromatogram of fatty acid methyl esters of infant milk formula in our chromatographic conditions.

Chromatogramme typique des esters méthyliques des acides gras d'une préparation pour allaitement des nourrissons dans nos conditions chromatographiques. samples (pre-term, adapted, follow-up and special).

Capillary gas chromatographic results are presented in table II. This table shows the total saturated fatty acids and the different percentages of unsaturated cis and trans isomers of $\mathrm{C}_{16: 1}, \mathrm{C}_{18: 1}, \mathrm{C}_{18: 2}$ and $\mathrm{C}_{18: 3}$. Results for $\mathrm{C}_{18: 1}$ trans range be-

Table I. Total trans isomer content by infrared and capillary gas chromatrographic techniques. Taux d'isomères trans par infrarouge et par chromatographie capillaire en phase gazeuse.

\begin{tabular}{|c|c|c|c|}
\hline $\begin{array}{l}\text { Sample } \\
\text { No }\end{array}$ & $\begin{array}{l}\text { Type of } \\
\text { Formula }\end{array}$ & $\begin{array}{l}\text { IR results } \\
\% \text { trans } \\
\text { isomers }\end{array}$ & $\begin{array}{l}\text { CGC results } \\
\% \text { trans } \\
\text { isomers }\end{array}$ \\
\hline $\begin{array}{l}01^{*} \\
02^{*} \\
03\end{array}$ & $\begin{array}{l}\text { (PT) } \\
\text { (PT) } \\
\text { (PT) }\end{array}$ & $\begin{array}{l}3.68 \\
2.50 \\
3.09\end{array}$ & $\begin{array}{l}2.49 \\
2.55 \\
1.19\end{array}$ \\
\hline $\begin{array}{l}04^{*} \\
05^{\star} \\
06 \\
07^{\star} \\
08 \\
09^{\star} \\
10^{\star} \\
11 \\
12^{\star} \\
13^{\star}\end{array}$ & $\begin{array}{l}\text { (AD) } \\
(A D) \\
(A D) \\
(A D) \\
(A D) \\
(A D) \\
(A D) \\
(A D) \\
(A D) \\
(A D)\end{array}$ & $\begin{array}{l}2.76 \\
3.15 \\
2.15 \\
2.88 \\
1.80 \\
3.40 \\
3.37 \\
1.68 \\
4.55 \\
2.57\end{array}$ & $\begin{array}{l}2.24 \\
4.54 \\
1.52 \\
2.54 \\
1.28 \\
4.06 \\
4.24 \\
1.74 \\
4.01 \\
2.61\end{array}$ \\
\hline $\begin{array}{l}14^{\star} \\
15^{\star} \\
16^{\star} \\
17 \\
18 \\
19^{\star} \\
20^{*}\end{array}$ & $\begin{array}{l}\text { (FU) } \\
\text { (FU) } \\
\text { (FU) } \\
\text { (FU) } \\
\text { (FU) } \\
\text { (FU) } \\
\text { (FU) }\end{array}$ & $\begin{array}{l}4.11 \\
2.27 \\
2.34 \\
1.43 \\
2.30 \\
3.15 \\
2.21\end{array}$ & $\begin{array}{l}3.98 \\
2.80 \\
3.39 \\
0.96 \\
3.58 \\
2.14 \\
2.59\end{array}$ \\
\hline $\begin{array}{l}21 \\
22 \\
23^{*} \\
24^{*} \\
25^{*} \\
26^{*} \\
27 \\
28\end{array}$ & $\begin{array}{l}\text { (SP) } \\
\text { (SP) } \\
\text { (SP) } \\
\text { (SP) } \\
\text { (SP) } \\
\text { (SP) } \\
\text { (SP) } \\
\text { (SP) }\end{array}$ & $\begin{array}{l}2.73 \\
2.98 \\
1.45 \\
4.04 \\
1.63 \\
3.82 \\
0.94 \\
2.37\end{array}$ & $\begin{array}{l}1.65 \\
1.40 \\
2.53 \\
2.14 \\
0.16 \\
2.61 \\
0.60 \\
2.06\end{array}$ \\
\hline
\end{tabular}

* with whole milk as ingredient. 
Table II. Capillary gas chromatographic results.

Résultats obtenus par chromatographie capillaire en phase gazeuse.

\begin{tabular}{|c|c|c|c|c|c|c|c|c|c|c|c|c|}
\hline \multirow{3}{*}{$\begin{array}{c}\text { Sample } \\
\text { No }\end{array}$} & \multirow{3}{*}{$\begin{array}{l}\text { Type of } \\
\text { formula s }\end{array}$} & \multirow{3}{*}{$\begin{array}{c}\% \text { total } \\
\text { saturated }\end{array}$} & \multicolumn{10}{|c|}{ CGC results (relative percentages) } \\
\hline & & & \multicolumn{4}{|c|}{$\%$ cis isomers } & \multicolumn{6}{|c|}{$\%$ trans isomers } \\
\hline & & & $16: 1$ & $18: 1$ & $18: 2$ & $18: 3$ & $16: 1$ & $18: 1$ & $18: 2 \mathrm{ct}$ & $18: 2 t c 1$ & $18: 2 \mathrm{tt}$ & $\begin{array}{l}\text { Others } \\
18: 3\end{array}$ \\
\hline $01^{*}$ & (PT) & 73.76 & 0.53 & 15.53 & 7.42 & 0.27 & 0.22 & 0.95 & 0.63 & 0.36 & nd & 0.33 \\
\hline $02^{*}$ & (PT) & 62.23 & 0.24 & 24.01 & 10.85 & 0.12 & nd & 2.15 & 0.12 & 0.08 & 0.08 & 0.12 \\
\hline 03 & (PT) & 62.99 & 0.77 & 27.57 & 7.30 & 0.18 & nd & 0.37 & 0.30 & 0.22 & nd & 0.30 \\
\hline $04^{*}$ & (AD) & 61.67 & 0.53 & 26.07 & 9.10 & 0.39 & 0.19 & 1.38 & 0.18 & 0.08 & nd & 0.41 \\
\hline $05^{*}$ & (AD) & 56.77 & 0.87 & 24.87 & 12.53 & 0.42 & 0.41 & 2.22 & 0.88 & 0.52 & nd & 0.51 \\
\hline 06 & (AD) & 46.50 & 1.52 & 39.05 & 11.16 & 0.25 & 0.15 & 0.42 & 0.41 & 0.29 & nd & 0.25 \\
\hline $07^{*}$ & (AD) & 57.68 & 0.28 & 26.71 & 12.59 & 0.20 & 0.10 & 2.10 & 0.11 & 0.12 & 0.11 & nd \\
\hline 08 & (AD) & 42.52 & 1.45 & 44.27 & 10.23 & 0.25 & 0.08 & 0.19 & 0.23 & 0.17 & nd & 0.61 \\
\hline $09^{*}$ & (AD) & 56.44 & 0.63 & 27.04 & 11.45 & 0.38 & 0.25 & 3.15 & 0.21 & 0.10 & nd & 0.35 \\
\hline $10^{*}$ & (AD) & 60.01 & 0.62 & 24.18 & 10.48 & 0.47 & 0.21 & 3.12 & 0.19 & 0.11 & 0.05 & 0.56 \\
\hline 11 & (AD) & 54.62 & 0.30 & 23.54 & 19.50 & 0.30 & 0.10 & 0.47 & 0.50 & 0.33 & nd & 0.34 \\
\hline $12^{*}$ & (AD) & 59.76 & 0.79 & 23.35 & 11.49 & 0.60 & 0.39 & 1.82 & 0.78 & 0.38 & 0.05 & 0.59 \\
\hline $13^{*}$ & (AD) & 56.12 & 0.23 & 27.79 & 13.08 & 0.17 & 0.07 & 2.07 & 0.13 & 0.12 & nd & 0.22 \\
\hline $14^{*}$ & (FU) & 58.84 & 0.59 & 25.19 & 10.97 & 0.43 & 0.19 & 3.01 & 0.17 & 0.11 & 0.06 & 0.44 \\
\hline $15^{*}$ & (FU) & 58.18 & 0.41 & 26.99 & 11.47 & 0.15 & 0.16 & 2.16 & 0.10 & 0.10 & 0.10 & 0.21 \\
\hline $16^{*}$ & (FU) & 57.44 & 0.84 & 23.80 & 13.98 & 0.55 & 0.39 & 2.00 & 0.18 & 0.07 & 0.06 & 0.69 \\
\hline 17 & (FU) & 47.80 & 0.28 & 34.74 & 13.14 & 0.08 & 0.10 & 0.23 & 0.25 & 0.16 & nd & 0.22 \\
\hline 18 & (FU) & 55.93 & 0.69 & 27.04 & 12.57 & 0.19 & 0.25 & 2.67 & 0.19 & 0.14 & 0.07 & 0.26 \\
\hline $19^{*}$ & $(F U)$ & 57.47 & 1.12 & 32.34 & 6.72 & 0.21 & 0.29 & 0.60 & 0.40 & 0.21 & 0.04 & 0.60 \\
\hline $20^{\star}$ & $(F U)$ & 56.92 & 0.26 & 27.51 & 12.61 & 0.11 & 0.08 & 1.97 & 0.17 & 0.11 & 0.10 & 0.16 \\
\hline 21 & (SP) & 66.19 & 0.06 & 20.62 & 11.39 & 0.09 & nd & 1.45 & 0.09 & 0.11 & nd & nd \\
\hline 22 & (SP) & 46.02 & 0.63 & 41.69 & 10.06 & 0.20 & 0.07 & 0.20 & 0.43 & 0.28 & nd & 0.42 \\
\hline $23^{*}$ & (SP) & 57.03 & 0.87 & 21.56 & 17.57 & 0.44 & 0.36 & 1.05 & 0.04 & nd & nd & 1.08 \\
\hline $24^{*}$ & (SP) & 56.38 & 0.63 & 28.95 & 11.43 & 0.47 & 0.28 & 0.77 & 0.18 & 0.11 & 0.05 & 0.75 \\
\hline $25^{*}$ & (SP) & 73.71 & 0.27 & 11.81 & 13.56 & 0.49 & 0.07 & 0.04 & 0.05 & nd & nd & nd \\
\hline $26^{\star}$ & (SP) & 57.14 & 0.25 & 26.91 & 12.98 & 0.11 & 0.07 & 1.88 & 0.15 & 0.11 & 0.10 & 0.30 \\
\hline 27 & (SP) & 43.84 & 0.11 & 26.29 & 27.28 & 1.88 & nd & 0.23 & 0.09 & nd & nd & 0.28 \\
\hline 28 & (SP) & 53.06 & 0.66 & 26.67 & 17.31 & 0.24 & 0.15 & 0.59 & 0.57 & 0.38 & nd & 0.37 \\
\hline
\end{tabular}

$n d=$ no detectable amount; * with whole milk as ingredient.

tween 0.04 and $3.15 \%$. These values are generally lower than those reported for human milkfat that range between $2-4 \%$ for this fatty acid (Emken, 1979). On the other hand, infant formulas that include whole cow's milk as an ingredient have higher values in trans isomers (average value $=$ $1.8 \%$ ) due to vaccenic acid formed in the biohydrogenation than formulas manufactured with skimmed milk (average value $=$ 
$0.97 \%$ ). Levels for the individual trans isomers of linoleic acid $\left(\mathrm{C}_{18: 2}\right)$, generally provided by the vegetable fat added to the formula, were less than $1 \%$ and only 1 sample (No 18) from the group manufactured with skimmed milk as a raw material shows $\mathrm{C}_{18: 2} t$ - $t$ isomers. Our results indicate that formulas manufactured with skimmed milk as an ingredient do not generally include hydrogenated vegetable fat and that the food industry complies with the EEC Proposal $85 / C 28 / 05$ that limits the use of fats with a maximum of $8 \%$ trans isomers, and that trans isomer content of infant milk formulas is lower than in cow's milk fat and human milk fat.

\section{REFERENCES}

Deman L, Deman JM (1983) Trans fatty acids in milkfat. J Am Oil Chem Soc 60, 1095-1098

Emken EA (1979) In: Geometrical and Positional fatty Acid Isomers (Emken EA, Dutton HJ, eds) J Am Oil Chem Soc, Champaign, IL, 99129

Emken EA (1981) Metabolic aspects of positional monounsaturated fatty acid isomers. $J A m$ Oil Chem Soc 58, 278-283
Hachey DC, Thomas MR, Emken EA, Garza C, Brownbooth C, Adolf RO, Klein PD (1987) Human lactation: Maternal transfer of dietary triglycerides labeled with stable isotopes. $J$ Lipid Res 28, 1185-1192

Hernandez N (1988) Technology and nutritive value of edible fats: vitamin $E$ and isomeric forms of fatty acids. Ph D Thesis, University of Barcelona, Spain

Koletzko B, Mrotzek M, Bremer HJ (1988) Fatty acid composition of mature human milk in Germany. Am J Clin Nutr 47, 954-959

Kummerow FA (1986) Dietary effects of trans fatty acids. J Environ Pathol Toxicol 6, 123149

Lee TW (1987) Quantitative determination of linoleic acid in infant formula by gas chromatography. J Assoc Off Anal Chem 70, 702-705

Parodi PW (1983) Relationship between fatty acid composition and triglyceride structure of bovine milk fat. J Dairy Res $50,443-447$

Slover HT, Lanza E (1979) Quantitative analysis of food fatty acids by capillary gas chromatography. J Am Oil Chem Soc 56, 933-943

Sommerfeld M (1983) Trans unsaturated fatty acids in natural products and processed foods. Prog Lipid Res 22, 221-233

Zegarska Z, Kuzdzal-Savoie S (1988) Seasonal effects on the fatty acids content in milk fat. Milchwissenschaft 43, 777-779 